(REVIEW ARTICLE)

\title{
The analysis of environmental factor for improving of navy resources performance
}

\author{
I Made Jiwa Astika and Okol Sri Suharyo * \\ Sekolah Tinggi Teknologi Angkatan Laut, STTAL Surabaya, Indonesia.
}

Global Journal of Engineering and Technology Advances, 2021, 06(03), 049-055

Publication history: Received on 25 January 2021; revised on 28 February 2021; accepted on 02 March 2021

Article DOI: https://doi.org/10.30574/gjeta.2021.6.3.0034

\begin{abstract}
There are things that must be owned for every soldier to improve optimal performance, namely the development of competence. This scientific work is motivated by the importance of the role of management of Navy Resources which is closely related to performance, in this case, the Navy soldiers. Based on the results of the study, a person who has adequate experience and technical qualifications do not necessarily have a good performance, if the person concerned is not able to show behavior that supports the implementation of the task. For this reason, the need for technical competencies can be developed through education and training aimed at improving knowledge and skills. For behavioral competencies alone can be done through various training programs and individual development aimed at changing behavior. Whereas organizational values that form institutional competencies can be instilled through indoctrination. Management of competency-based warrior performance is a current method in the field of behavioral science, which can be used to improve the quality of Navy capital in order to support the realization of a minimum essential force. Considering that as part of the government's bureaucratic reform program, the Indonesian Ministry of Defense has adopted a competency-based personnel management system, so the Navy Institution must inevitably integrate it into the Navy personnel development system.
\end{abstract}

Keywords: Environmental Factor; Navy Resources; Performance of Indonesian Navy

\section{Introduction}

In order to be able to carry out main tasks and functions properly, the formation of Navy personnel is directed at improving the quality of Navy resources, in order to have an attitude and behavior so as to provide the best service (excellent service) and high performance for the glory of the nation and the State. The position and role of the Navy as the main element of defense forces in the Sea which has the main tasks and functions according to Law No. 34 of 2004, namely the Navy Institution is required to play an active role in maintaining and maintaining the sovereignty of the Republic of Indonesia by being based on loyalty and obedience to Pancasila and the 1945 Indonesian Constitution.

Navy resources (NR) are often referred to as Navy resources, power or Navy strength (energy or power). Resources are also called sources of energy, ability, strength, expertise possessed by Navy. Along with the development of technology and changes in the world that are increasingly complex, demanding someone to always refresh their abilities in accordance with the capacity of these changes. Basically, Navy have basic potential and abilities that will ideally continue to develop if continuously and continuously honed (Mashood, 2014). The implementation of national defense relies on the strength and ability of Navy resources, namely the Indonesian people, both military and non-military, who are supported by a reliable weapon system and defense management, so that qualified Navy resources are a center of strength for National Defense. In the 2008 Indonesian Defense White Paper it was stated that improving the quality and welfare of defense Navy resources became one of the main targets in addition to efforts to increase defense capability,

\footnotetext{
${ }^{*}$ Corresponding author: Okol Sri Suharyo

Global Journal of Engineering and Technology Advances, 2021, XX(XX), XXX-XXX.
} 
rejuvenation and addition of defense equipment and improvement of domestic defense technology and industry (Indonesian Defense White Paper 2008, Ministry of Defense Republic of Indonesia, Jakarta)

Based on the background above, several problems can be formulated which underlie this research as follows: what factors influence the performance of Navy soldiers, how the relationship and influence of NR on the performance of the Navy, how to improve the performance of Navy soldiers, and how is the relationship of competence to the performance support tools of the Navy to find out and analyze the strong influence of NR on Navy performance. The final goal of this research is to obtain key factors that can be carried out by the Indonesian Navy management in order to improve and realize the competency-based optimal performance of Indonesian Navy personnel.

\section{Material and methods}

\subsection{The Indonesia Navy}

The strength of the Navy is currently divided into 3 (three) Co-operatives, Command Fleet I based in Tanjung Priok, Jakarta, Command Fleet II which is based in Tanjung Perak Surabaya, and Command Fleet III which is based in Sorong Papua, besides that, it also oversees the Marine Corps. In accordance with Law No. 34 of 2004 concerning the TNI in Article 9, the Navy is in charge of:

- Carry out the tasks of the TNI in the defense sector;

- Enforce the law and maintain security in the sea area of national jurisdiction in accordance with the provisions of national law and international law that has been ratified;

- Carry out the duties of the Navy's diplomacy in the framework of supporting foreign policy set by the government;

- Carry out the duties of the TNI in the development and development of the power of the sea dimension, and

- Carry out empowerment of sea defense areas;

The Indonesia National Navy Forces are part of the Indonesian Military Forces (TNI) which are responsible for the defense operations of the Republic of Indonesia in the Sea. The Navy was formed on September 10, 1945. Nowadays The Indonesian Navy is led by a Navy Chief of Staff who is the highest leader in Naval Headquarters.

In carrying out its main duties, the Navy has a defense function and enforces Marine law carried out by the Main command in the Navy. The Main command in the ranks of the Navy has the Fleet Command, under the Koarmada there is the Main Base of the Navy, besides that the Fleet Command also has an Operation Unit (Combat Group / Security Group) and Implementing Unit (Fast Ship, Ship Amphibians, Submarines). Under the Main Base of the Navy, there is the Naval Base. While for the Implementing Unit in charge of the Fleets, namely the Republic of Indonesia Warship.

\subsection{Navy Resources}

Navy Resources is an integrated ability of the mind and physical power possessed by an individual and institutional. Actors and their characteristics are carried out by their offspring and environment, while their work performance is motivated by the desire to fulfill their satisfaction. Navy Resources consists of the power of thought and physical power of every Navy being, (Iqbal, 2015). Strictly the ability of every Navy being is determined by the power of thought and physical power. NR or Navy Resources are the main elements in every activity carried out. Reliable or sophisticated equipment without active NR roles does not mean anything. Thinking power is intelligence that is carried out from birth (basic capital) while skills are obtained from business (learning and training). Measuring intelligence is Intelligence Quotient (IQ) and Emotion Quality (EQ).

Some goals for agencies related to competency-based Navy resource management, (Singh, 2013), for example:

- All positions within the organization can function properly (according to the demands of their work).

- Provide guidance to all officeholders in order to meet the prescribed measures of position competency standards.

- As a basis for NRD to develop competency and career development programs based on the results of competency measurements compared to the requirements on job competencies held by them.

- To improve one's competence if at the time of competency measurement it is found that the competencies have not been able to meet the position of competency requirements through training programs, coaching, and counseling. 
Navy resources are very critical factors as the main assets in an agency. Its existence in the system with all its uniqueness which greatly determines success becomes very important to note. For this reason, agencies must develop their management strategies well and orderly (Zameer, 2014). The Navy ability factor in carrying out its work is strongly influenced by the competencies that are in each of them so that Navy Resource Management (NR Management) based on competency management sees that the need for output from each worker makes competency the main foundation for all functions in NRM, (Khan, 2014).

Competence drives the work system design process, recruitment, placement, performance management, and with all functions in NRM. Therefore, each person certainly has criteria and measures of competency, each of which is different and has its own characteristics (Vosloban, 2012). But not everyone can fulfill the demands of their competency. For this reason, it is also necessary to identify, measure and analyze these competencies and their management so that the functions of competency development programs for Navy resources can be prepared through appropriate competency improvement programs, for example through training, coaching and/or programs counseling (Parvin, 2011).

\subsection{Environmental Factors for Affecting Performance}

A person who has adequate technical experience and qualifications does not necessarily have a good performance if the person concerned is not able to demonstrate the behavior that supports the implementation of his duties and position. Behavioral competencies can basically be measured through what is called the Assessment Center (Rania, 2011)

Research in the field of personnel management shows the performance of an individual determined by four factors, namely, experience, technical competence (hard skills), behavioral competencies (soft skills) and personality (Latif, 2013). Experience is related to what has been done by someone and can be measured through job history analysis, results of performance appraisal, and track record owned. On the other hand, technical competence refers to what someone already knows, and can be measured through professional qualifications (for example, from certificates and diplomas), or through ability tests or competency tests. Behavioral and personality competencies, which are more related to psychological aspects, are related to what can be done by someone (Shmailan, 2016). Of these four factors (experience, technical competence, behavioral competencies, and personality), personality is regarded as the center of optimal sources of performance and influences all other factors. In addition to these four factors, there is actually still one more factor, namely institutional competence, which includes typical organizational values, so that it can influence one's performance. However, until today, there is no scientific measurement tool, it can be used to measure how far someone has made certain values as a handle of his life (Sageer, 2012).

\subsection{Relationship of Navy Resources and the Institution}

The Navy as one of the dimensions in the Indonesian Military is currently experiencing a period, where between the demands of the task and the threat of the threat to put the Navy in a difficult position, because until now to be able to meet the minimum essential force needs it is still difficult to achieve, while the nature of the threat is increasingly complex along with the times. The real threat currently faced by the nation and state of Indonesia is a large number of internal conflicts both vertical and horizontal conflicts that can threaten the integrity of the Republic of Indonesia, not to mention the threat from outside countries trying to tamper with the sovereignty of the Republic of Indonesia through shifting regional borders, annexation and claimants and islands, as well as guarding our outer islands which are very vulnerable to disruption and control by other countries.

State sovereignty, national defense, and the Navy are three things that cannot be separated because in carrying out national defense in order to guarantee the upholding of the Republic of Indonesia, the main component is the Navy. Therefore building the Navy and its ranks to be strong, solid and professional is a necessity at this time. But building the Navy, especially the Navy is not as easy as it says, because building the Navy as a large military organization requires attention and cooperation from all components of the nation. Because building the Navy requires policy, regulation, and budget and posture reform. Whereas we know after the reform, the Navy faced a lot of blasphemy and criticism from various circles, besides that the state's own financial condition had not fully improved, so the budget support to the defense sector was also very limited which eventually became an obstacle in the development of the Navy.

Such things eventually led to a contemplation, could the Navy maintain the sovereignty of the Republic of Indonesia, and could we build a reliable and respected Navy and world-class Navy. This kind of reflection must be realized, because the Navy which is reliable and respected and world class, is one of the tools to achieve the national goals and ideals of the Indonesian nation even though it requires time but at least there are solutions that can be used and applied to lead to the achievement of a reliable and respected and world-class Navy organization. The development of a military organization as an institution in charge of the defense sector has its own peculiarities, because military organizations besides having 3 (three) main factors forming the organization, namely: 1) People, 2) Cooperation and 3) Specific 
objectives, where all three factors it is interrelated and inseparable, it also has additional factors according to its characteristics, in this case, there is a doctrine in carrying out national defense strategies. It is from this doctrine that then gives birth to policies, basic principles and strategic steps for managing defense resources to build military organizations in order to achieve national goals, (Elqadri, 2015). Likewise with the Navy as a military organization that has a main task, among others, carrying out the tasks of the military in the defense sector, carrying out the tasks of the TNI in the development and development of the power of the sea, all forms of activities carried out by the Navy the management of its defense resources is directed towards forming a reliable and respected Navy and world-class organization. Therefore the Navy's defense resource management policy must refer to the national defense strategy. So that the translation can be integrated with each other.

\section{Results and discussion}

\subsection{Development on Environmental Factors}

To build a World-Class Navy, the priority is to build character, both individual characters, units and organizations of the Navy in its entirety and thoroughly. The characters needed are superior, special, and high quality or called "Excellent". Excellent in four fields, namely in the fields of Organization, Operations, Navy Resources, and Technology, as shown in Figure 1 below:

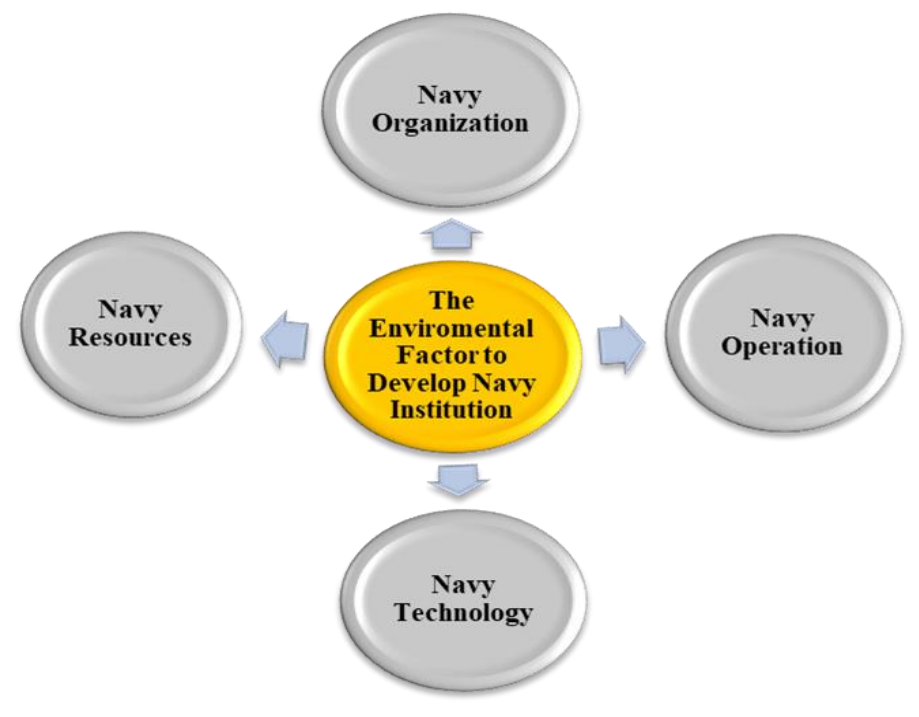

Figure 1 The Environmental Factors to Develop Navy Institution

In Figure 1, it can be explained that to develop the Indonesian Navy it is necessary to build character in all fields related to the basic tasks of the Indonesian Navy, namely organization, operations, Navy resources, and technology. This is very necessary to be able to make the Navy become a world-class Navy institution.

In terms of competency development, basically, the experience can be improved by providing opportunities in various positions, while technical competencies can be developed through education and training aimed at improving knowledge and skills. For behavioral competencies, development programs that can be carried out are tNRough various training and individual development programs that aim to change behavior, while organizational values that shape institutional competence can be instilled through indoctrination. However, Navy personality, both from inheritance (personality or IQ), or formed from the past, is something that is relatively settled and difficult to change, namely the development of character, (Chukwuma, 2014).

\subsection{Excellence Environmental Based Approach}

In the context of behavioral competencies, the main goal in developing behaviors that support optimal performance is mapping the relationship between personalities that can support behavioral competencies that are expected to exist within the organization. For individuals who have inadequate behavioral competencies, they can be included in the development program so that in the future they can show optimal performance. For example, based on research, it is known that competencies related to interpersonal flexibility are strongly influenced by the inherent traits of extroversion and adaptability, while competencies associated with innovative thinking abilities are influenced by the 
level of intelligence (IQ) possessed and the innate nature of new experiences. Therefore, if an individual with a supportive personality has been found, the individual can be included in a behavioral competency development program that is related to interpersonal flexibility and innovative thinking, so that ultimately an individual can be flexible and innovative, (Awadh, 2013).

Behavioral scientists have formulated the concept of the strengths-based approach, which aims to place an individual according to his personality, and then develop his competence and experience. According to this thought, it is more useful to look for a personality that can be someone's strength, and then develop competencies that can be supported by that personality. For example, extroverted innate traits are known to support interpersonal competence, so extroverted individuals are easier to develop in positions that require interaction with other Navys (Al-Mzary, 2015).

\subsection{Key Factors for Increasing Development Navy Resources}

To be able to answer the challenges of an increasingly complex task, the Navy must be able to carry out improvements and empowerment of its Navy resources to be able to create superior and professional Navy personnel, the description can be described by some key factors as shown in Figure 2 below:

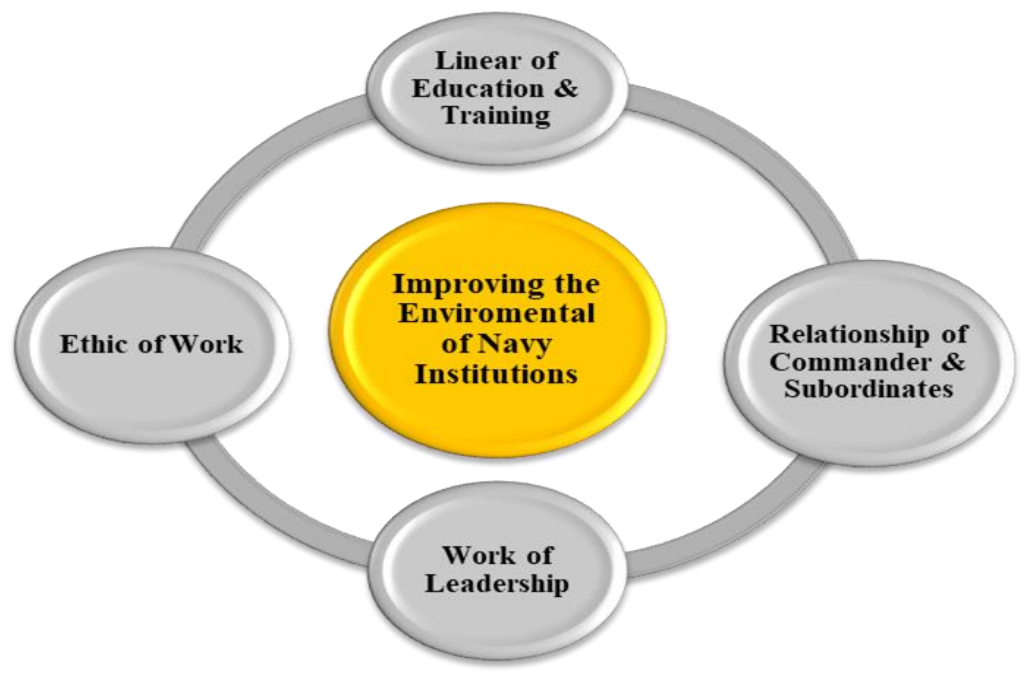

Figure 2 Improving the Environmental of Navy Resources

The development of the Navy resources of the Navy is emphasized on the modernization of the Navy aspect where Navys are placed in important positions in the Navy's organization. Thus, the development of Navy resources is a central point in the development of the strength and capability of the Navy which is expected to determine the success of carrying out basic tasks. Referring to this reasoning, the Navy's Navy resource development must be carried out conceptually, systematically, planning and continuing. In this context, coaching must be carried out under any circumstances, either with full budget support or limited budget support, because basically, Navys are living things that have specificities, namely feelings, thoughts and reason, and dynamic knowledge. For this reason, several key factors can be formulated that can improve the professionalism of Navy personnel by improving the quality of Navy resources through a. Improving the quality of education and training, b. Improving work ethics, c. Improving the relationship between commanders and subordinates, and d. Good leadership at every level of office.

\subsubsection{Linear Education and training}

First, Linear Education and training that aim to equip, maintain and improve the quality of personnel basically have been carried out within the Navy, only in the present context and the influence of the strategic environment of education and training that they are improved by connecting issues around the world of defense with material and curriculum in the military education world. Especially if it is associated with the RMA where the development of science and technology is very influential on the defense sector, education and training naturally in the environment of the Navy are developed and adapted based on mastery of technology, because the development of RMA has influenced the strategy and tactics of operations. 


\subsubsection{Improving Ethic of Work}

A good work ethos will produce productive, efficient personnel who are capable of completing tasks and job responsibilities proportionally and professionally. So far, the Navy still looks ineffective and efficient in the way the personnel work so productivity is not optimally achieved. To be able to improve the work ethic, there is a need for a fundamental change in the work environment of each unit at each level of office by making work standards and personnel who work on them by paying attention to:

- Conformity, the right personnel in the right job so that productivity can be achieved.

- Guarantees, the trust, and confidence that every work achievement will get a decent award.

- Attention, that none of the work is important even though the work is very easy to do.

- Supervision, the most important part of the mechanism of a job because it relates to the timeliness of work completion and the quality of work.

- Evaluation, an important factor to determine the extent of achieving the task.

- Actions, sanctions if there is a delay or the task is not resolved. By paying attention to these six factors, the reward and punishment system can be enforced and a better work ethic can be implemented.

\subsubsection{Improving Commander and subordinate relations}

That the success of the unit in carrying out its main duties is not solely the duties and responsibilities of the Commander, but rather is a joint responsibility. This is where there is a need for teamwork or cooperation between commanders and subordinates. In cooperation here is needed a) honesty in each personnel, b) responsibility of each person to carry out the task properly and correctly, c) initiatives of the leadership elements to make changes and d) mutual assistance between the commander and subordinates in realizing the main goal or task unit. Good cooperation can be realized through increasing the relationship of commanders and subordinates, because if the commander element is more intensive to pay attention to his subordinates, then the reciprocity that will be obtained is the existence of high awareness and responsibility from subordinates to carry out each job properly and correctly.

\subsubsection{Work of Leadership}

The most decisive factor in forming a superior organization is good leadership. Likewise with the Navy, as a military organization in order to become a strong, solid and professional organization in addition to carrying out the guidance of its personnel, the last factor that can be fostered and directed towards better change is the presence of strong and reliable leadership factors in every level of position in the Navy. Establishing strong and reliable leadership has often been discussed and discussed within the Navy because policyholders in the Navy are well aware of the importance of leadership. But the implementation still feels lacking, this can be seen from the still small portion of subjects about leadership in educational institutions within the Navy. Although there are those who say that a reliable leader is born of his era, there are also leaders who are prepared. This prepared leader needs attention from the Navy to try to realize it through educational institutions or leadership training. By placing a greater portion on the formation of an earlier leadership, it is hoped that good leaders will emerge in the Navy who will be able to build the Navy into a reliable and respected world-class organization.

\section{Conclusion}

The development of science and technology in the field of personnel management, civil and military organizations in various countries, including in Indonesia, has adopted the method of managing competency-based personnel in order to improve the performance of their organizations. The Ministry of Defense of the Republic of Indonesia itself, as part of the Government's Bureaucratic Reformation, has launched the concept of competency-based personnel development in the ranks of the Navy Institution. Thus, the Navy certainly needs to make various improvements in the field of personal development so that it can properly implement the competency-based personnel management method. Through the implementation of appropriate competency-based personnel management methods, it is expected that in the future the performance of the Navy personnel will be more optimal.

The dynamics of The Navy organization are in line with the dynamics of other RI government institutions. One of the national dynamics that influenced the TNI organization was the national reform movement as a result of the fall of the New Order regime in 1998 (Indonesian Ministry of Defense, 2012). This dynamic has brought the Navy to carry out the same reform program in order to position itself appropriately and optimize its role in the national life order. Bureaucratic reform carried out within the TNI includes aspects of doctrine, structure, and culture that are in line with the national bureaucratic reform policy to realize clean and authoritative governance occur nationally, in order to create effective and efficient governance. While the cultural aspects are directed at changing the mindset of Personnel and 
compliance with the law and Navy rights and Personnel discipline in carrying out basic tasks as mandated in Republic of Indonesia Law Number 34 of 2004 concerning the Navy.

\section{Compliance with ethical standards}

\section{Acknowledgments}

The authors greatly acknowledge the support from Sekolah Tinggi Teknologi Angkatan Laut STTAL Surabaya and Indonesian Navy Institution for providing necessary resources to carry out this research work. The authors are also grateful to the anonymous reviewers and journal editorial board for their many insightful comments, which have significantly improved this article.

\section{Disclosure of conflict of interest}

The authors declare no conflict of interest.

\section{References}

[1] Al-Mzary MM, Al-rifai, AlMomany MO. Training and its Impact on the Performance of Employees at Jordanian Universities from the Perspective of Employees: The Case of Yarmouk University. Journal of Education and Practice. 2015; 128-140.

[2] Awadh AM, Alyahya MS. Impact of Organizational Culture on Employee Performance. International Review and Business Research. 2013; 168-174.

[3] Chukwuma, Maduka, Edwin, Okafor, Obiefuna D. Effect of motivation on employee Productivity: A study of Manufacturing Companies in Nnewi. International Journal of Managerial Studies and Research. 2014; $137-147$.

[4] Elqadri, Mustafa, Z, Wardoyo, Wijayanti DT, Priyono. The Influence of motivation and discipline work against Employee work productivity Tonaan Market. Review of European Studies. 2015; 59-66.

[5] Iqbal A, Ijaz M, Latif F, Mushtaq H. Factors Affecting The Employee's Performance: A Case Study Of Banking Sector In Pakistan. European Journal of Business and Social Sciences. 2015; 309-318.

[6] Khan Hussain A, Aleem, Muhammad. Impact of satisfaction on employee turnover: An empirical study of Autonomous Medical Institution of Pakistan. Journal of International Studies. 2014; 122-132.

[7] Latif, Shahzad M. Impact of Employees Job Satisfaction on Organizational Performance. European Journal of Business and Management. 2013; 166-171.

[8] Mashood, Ayesha. Factors Affecting Employee Satisfaction of Public and private sector organization of Pakistan. International Journal of Navy Resources Studies. 2014; 97-121.

[9] Parvin, Mahamuda M. Factors Affecting Employee Job Satisfaction in the Pharmaceutical Sector. Australian Journal of Business and Management Research. 2011; 113-123.

[10] Rania, Sakthivel, Kamalanabhan, Selvarina. Work/Life balance Reflection on Employees Satisfaction. Serbian Journal of Mangement. 2011; 85-96.

[11] Sageer, Alam, Rafat, Sameena D, Agarwal, Puja M. Identification of Variables Affecting Employees Satisfaction. IOSR Journal of Business and Management (IOSR-JBM). 2012; 32-39.

[12] Shmailan, Bin AS. The relationship between job satisfaction, job performance, and employee engagement. Issues in Business Management and Economics. 2016; 1-8.

[13] Singh Kumar J, Jain, Mini D. A Study of Employees Job Satisfaction and its Impact on their Performance. Journal of Indian Research. 2013; 105-111.

[14] Vosloban RI. The Influence of the Employee's Performance on the company's growth - a managerial perspective. Procedia Economics and Finance Journal. 2012; 660-665.

[15] Zameer H, Ali S, Nisar W, Amir M. The Impact of the Motivation on the Employee's Performance in Beverage Industry of Pakistan. International Journal of Academic Research in Accounting, Finance and Management Sciences. 2014; 293-298. 